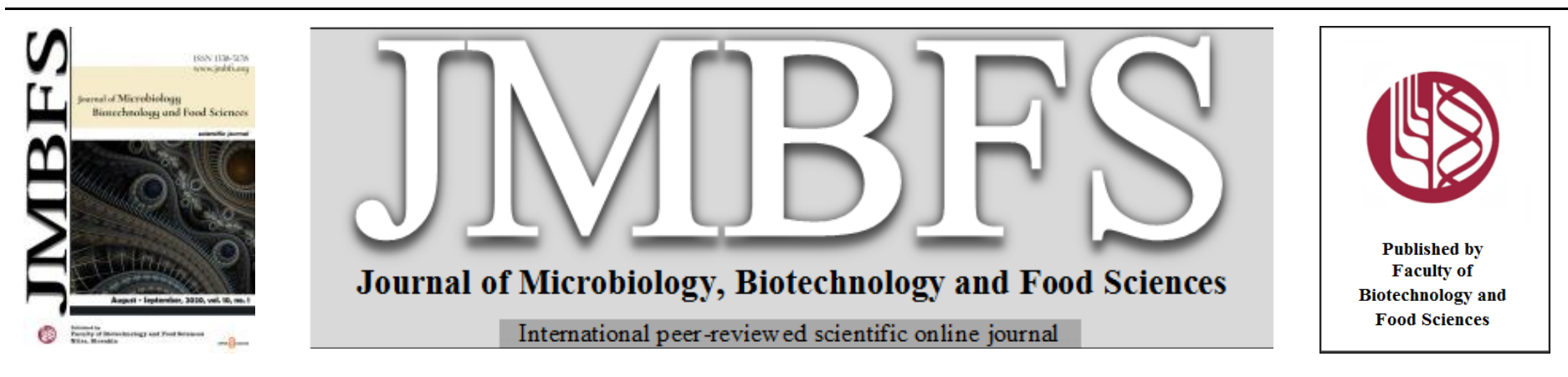

\title{
IN VITRO ANTIBACTERIAL, ANTIOXIDANT, CYTOGENOTOXIC AND NUTRITIONAL VALUE OF ALOE BARBADENSIS MILL. (ASPHODELACEAE)
}

\author{
Joseph Omorogiuwa Erhabor ${ }^{* 1,2,3}$ and MacDonald Idu ${ }^{1}$ \\ Address(es): Dr Joseph O. Erhabor, \\ ${ }^{1}$ Permanent Address: Phytomedicine Unit, Department of Plant Biology and Biotechnology, University of Benin, PMB 1154, Benin City, Nigeria. \\ ${ }^{2}$ Phytomedicine Programme, Department of Paraclinical Sciences, Faculty of Veterinary Sciences, University of Pretoria, South Africa. \\ ${ }^{3}$ IKS Research Group, Department of Pharmacology, Faculty of Health Sciences, University of the Free State, South Africa.
}

*Corresponding author: joseph.erhabor@uniben.edu

doi: 10.15414/jmbfs.2020.10.1.12-21

ARTICLE INFO

Received 19. 5. 2019

Revised 18. 2. 2020

Accepted 3. 3. 2020

Published 1. 8. 2020

Regular article

OPEN $\partial_{\text {ACCESS }}$

\section{ABSTRACT}

This study evaluated the in vitro antibacterial, antioxidant, nutritional and cytogenotoxic potentials of Aloe barbadensis (AB) root extract. The antimicrobial activity of $\mathrm{AB}$ was determined using agar well diffusion and microdilution techniques while the nutritional analyses were done using standard procedures. The antioxidant activities were evaluated via the lipid peroxidation, 1, 1, diphenyl-2picrlhydrazyl (DPPH) and ferric reducing power (FRAP) assays. The cytogenotoxic effects were assessed using the Allium cepa and Sorghum bicolor assays. Five test bacterial isolates: Escherichia coli, Klebsiella pneumoniae, Proteus mirabilis, Pseudomonas aeruginosa and Staphylococcus saprophyticus) were found susceptible to the ethanolic extract of AB root. The extract at $50 \mathrm{mg} / \mathrm{ml}$ recorded the highest zone of inhibition $(25.00 \pm 1.73 \mathrm{~mm})$ against $S$. saprophyticus. The nutritional analysis gave a nitrogen free extract value of $24.66 \%, 30.05 \%$ crude fibre, $15.14 \mathrm{mg} / \mathrm{kg}$ of Na, $2.01 \mathrm{mg} / \mathrm{kg}$ of Mg, $37.42 \mathrm{mg} / \mathrm{kg}$ of Fe and $0.02 \mathrm{mg} . \mathrm{kg}$ of Zn. The fractions had antiradical activity in the lipid peroxidation, DPPH and FRAP assays. The ethanolic extract induced some chromosomal aberrations in the root tip cells of Allium cepa. The ethanolic extract had the highest $(0.13 \pm 0.09 \mathrm{~mm})$ antiproliferative activity at $20 \mathrm{mg} / \mathrm{kg}$ in the Sorghum bicolor assay. The relatively high nutrient content may be a possible mechanism for the aphrodisiac property of the plant. The results of the biological activities of $\mathrm{AB}$ root is an indication of its potential use in drug development for the management of infectious diseases and other related ailments.

Keywords: Aloe barbadensis, antibacterial, antioxidant, cytotoxicity, genotoxicity, microbial infections, phytochemicals

\section{INTRODUCTION}

Today medicinal plants are fast becoming an important key to unlock the ravaging effects of some diseases in the world. The World Health Organization (WHO) has supported traditional medicines, particularly in developing countries by promoting the incorporation of its useful elements into the national health care system (Akerele, 1987). This fortunately has led to the rising popularity of herbal medicine in developing countries (Obici et al., 2008). This affirms the belief that medicinal plants are nature's gift to mankind.

Aloe barbadensis (AB) of the family- Asphodelaceae has been reported ethnomedically to have several folks uses with some validated scientific information. Its ethnomedical use as an aphrodisiac was earlier reported by Erhabor et al. (2013) and this was validated in vivo using an animal model (Erhabor and Idu, 2017). Other previously reported biological activities of this plant include the use of its gel in wound healing (Davis et al., 1994; Maenthaisong et al., 2007), inflammatory problems (Che et al., 1991; Robbers and Tylers, 1999) as well as in moisturizing and anti-aging activities (West and Zhu, 2003; Sahu et al., 2013). The leaves have been used for treating fungal infections associated with superficial mycoses (Shamim et al., 2004). The antidiabetic property (Tanaka et al., 2006; Yagi $\boldsymbol{e t}$ al., 2006) and its perceived reproductive functions in enhancing fertility (Oyewopo et al., 2011; Iwu, 2014; have also been documented.

Some of the ethnomedical uses of A. barbadensis include its use in the treatment/management of intestinal ulcers (Ross, 1999), constipation, impotency, ringworm and eczema (Adodo, 2012). It is used as a purgative, appetite stimulant and emmenagogue, as well as in the treatment of colds, piles, asthma, cough and jaundice (Joseph and Raj, 2010). Interestingly, chemicals found in the plant have become known remedies for treating sexual disorders/reproductive diseases (Yakubu et al., 2007; Joseph and Raj, 2010), microbial infections (Usman et al., 2005; Idu et al., 2011; Erhabor et al., 2013;; Mongalo et al., 2017; Motlhatlego et al., 2018;), cancers ( Venables et al., 2016; Eboji et al., 2017) and free radicals implicated diseases ( Otang et al., 2012; Sharma and Lall,
2014; Elisha et al., 2015; Motlhatlego et al., 2018) as well as other relevant ailments/diseases. The medicinal value of plants lies in these chemical constituents or active ingredients and other nutrients for their actions (Edeoga, 2000; Okigbo et al., 2008). These plant chemicals have been reported to offer a boost of nutritional value thereby improving sexual performance and libido (Yakubu et al., 2007; Sumalatha et al., 2010). This enhancement in the general health can thus lead to a burst of energy which translates into increased sexual appetite, besides increasing blood flow and intensity of ejaculation accompanied by anabolic and growth hormone stimulating properties (Smith et al., 2000 Ahmad et al., 2003; Yakubu et al., 2007). These phytochemicals have also been reported to enhance erection and prolong ejaculatory latency in male albino rats (Yakubu et al., 2005; Muanya and Odukoya, 2008; Sumalatha et al., 2010) These bioactive substances from medicinal plants include saponins, alkaloids, flavonoids, tannins, sterols, protein, carbohydrates and several minerals (zinc, calcium, magnesium, potassium) (Olowokudejo et al., 2008). A. barbadensis following previous studies undertaken mainly on the leaves and gel has many of these bioactive phytochemical substances (Ross, 1999; Joseph and Raj, 2010; Adodo, 2012; Sahu et al., 2013; Idu et al., 2014). Among, these phytochemicals are those which may scavenge reactive oxygen species that have been implicated in damaging biological molecules (DNA, protein, carbohydrate and lipids), leading to cancer, infertility and other ailments (Ashafa et al., 2010; Raghuveer and Vyas, 2010). Despite the many merits of these phytochemicals, they are said to have a deleterious effect when not properly utilized or consumed. There is therefore a need to assess their safety levels either at the cell, tissue or organ levels

In this study, our objective was to determine the antimicrobial, antioxidant, nutritional and phytochemical constituents of the root of Aloe barbadensis as a potential aphrodisiac. The cytotoxic and genotoxic effects of the plant were also investigated. 


\section{METHODS}

\section{Collection of plant sample}

The roots of A. barbadensis were collected from Okene, Nigeria. It was authenticated by Mr. G. Ibhanesebhor of the Herbarium Unit of the Obafem Awolowo University, Ile-Ife, Nigeria, with voucher number-IFE17004 where it was deposited.

\section{Preparation of plant sample and extraction}

$A B$ roots were detached from the whole plant, rinsed in water, spread on laboratory tables and dried at room temperature. The roots were dried in an oven set at $40^{\circ} \mathrm{C}$ for 10 minutes before being reduced to a fine powder using a grinder Two kilograms $(2 \mathrm{~kg})$ of the powdered plant material was extracted with ethanol $(5 \mathrm{~L})$ using a Soxhlet extractor. The extract was concentrated to dryness using a water bath (HH-S Water Bath; Searchtech Instruments) set at an average temperature of $50{ }^{\circ} \mathrm{C}$. The percentage yield of the ethanolic extract was determined using the formula (\% yield = weight of extract/weight of powder material x 100/1).

\section{Preparation of solvent fractions}

Forty grams of the ethanolic extract was re-dissolved in $100 \mathrm{ml}$ of $60 \%$ methano and partitioned exhaustively with chloroform $(150 \mathrm{ml})$ in a separating funnel by decanting until a transparent layer was obtained. The lower layer-chloroform fraction (organic) was collected first and the upper layer- aqueous fraction (inorganic) was also collected. Water $(70 \mathrm{ml})$ was added to the chloroform to remove compounds that entered the bottom layer due to agitation. The chloroform fraction was further concentrated to dryness using a water bath at a relatively low temperature. Ethyl acetate $(300 \mathrm{ml})$ was added to the aqueous fraction and decanted appropriately. The ethyl acetate fraction, being less dense, was collected after decanting the aqueous fraction. Both fractions were then further concentrated using a water bath. The respective percentage yields of the fractions (chloroform, ethyl acetate and aqueous) were determined using the formula (\% yield= weight of extracted fraction/weight of crude extract X 100/1)

\section{Antimicrobial evaluation \\ Collection of semen samples}

The semen samples were collected according to the method previously described by Ekhaise and Richard (2008). The seminal fluid specimen was collected from five male patients attending a fertility clinic at two private hospitals in Benin City, Nigeria. The samples were collected from patients with secondary infertility using the masturbation method. The collected specimens were immediately transferred to the laboratory where they were further subjected to microbiological isolation and identification.

\section{Isolation, Identification and Standardization of test organisms}

The sperm specimens were streaked on both blood agar and nutrient agar. The plates were incubated at $37{ }^{\circ} \mathrm{C}$ for $24 \mathrm{hrs}$. After incubation, the bacterial species were identified via Gram staining and appropriate biochemical tests following standard procedures outlined by Cheesbrough (2006). A loop full of stock culture of the organism was inoculated onto $5 \mathrm{ml}$ of sterile Müller-Hinton agar and incubated for $24 \mathrm{hrs}$. Overnight culture of the organisms $(0.2 \mathrm{ml})$ was inoculated into $20 \mathrm{ml}$ of sterile nutrient broth and incubated for 3-5 hrs. The turbidity of the culture was compared to that of a 0.5 Mac-Farland standard to standardize the culture to $10^{6} \mathrm{cfu} \backslash \mathrm{ml}$.

\section{Susceptibility Testing}

According to the method described by Emeruwa (1982), $0.5 \mathrm{ml}$ of the standardized culture was spread onto a sterile plate to achieve confluent growth Fifteen milliliters of Müller-Hinton agar at $45^{\circ} \mathrm{C}$ was added to each plate and the plates rocked for even spread and proper mixing of bacteria and agar. The content of the plates was allowed to solidify and wells approximately $6 \mathrm{~mm}$ in diameter were bored on the surfaces of the agar medium using a sterile cork borer and the bottom of the holes seeded with molten agar. The reconstituted extract $(0.2 \mathrm{ml})$ at the test concentrations was dropped into the holes while an aqueous solution of the standard antibiotic (chloramphenicol) at the same concentrations as the extract was used as positive control. Sterile distilled water $(0.2 \mathrm{ml})$ was used as negative control. The plates were allowed to stand for 30 mins for pre-diffusion of the extract to occur and then incubated at $37{ }^{\circ} \mathrm{C}$ for $24 \mathrm{hrs}$ and zones of inhibition were measured to the nearest $\mathrm{cm}$ using a meter rule. The final measurements were converted to $\mathrm{mm}$. The mean of duplicate results was recorded.

\section{Determination of Minimum Inhibitory Concentration (MIC)}

Bacterial strains were cultured overnight at $37{ }^{\circ} \mathrm{C}$ on nutrient broth and were adjusted to a final density of $10^{6} \mathrm{cfulml}$. The standardized bacterial inocula were used to inoculate the 96-well microtitre plates containing appropriate dilutions of the extract $(12.5-0.10 \mathrm{mg} / \mathrm{ml})$ under sterile conditions. The plates were incubated under aerobic condition at $37{ }^{\circ} \mathrm{C}$ and examined after $24 \mathrm{hrs}$. As an indicator of bacterial growth, $40 \mu 1 \mathrm{of} 0.2 \mathrm{mg} / \mathrm{ml}$ p-iodonitrotetrazolium violet was added to each well and incubated for $30 \mathrm{mins}$ at $37{ }^{\circ} \mathrm{C}$. The colourless tetrazolium salt was reduced to a red coloured product by the biological activity of the organisms. Each treatment was performed in triplicate and complete suppression of growth at a specific concentration of extract as indicated by a clear solution was required for it to be recorded as active (Eloff, 1998) Chloramphenicol was used as positive control in the experiment with sample free solutions of $10 \%$ DMSO as the negative control.

\section{Determination of Minimum Bactericidal Concentration (MBC)}

The MBC was determined by removing a loopful of bacterial suspension from the MIC micro-titre plate that did not show any growth and sub -cultured into nutrient agar plates. The plates were incubated and the concentrations at which no visible growth was observed were recorded as MBC.

\section{Antioxidant activity}

\section{Lipid peroxidation assay}

This assay was carried out using a slightly modified method described by Ohkawa et al. (1979). Liver homogenate was prepared from commercially available goat liver sourced from a local abattoir in Benin City, Nigeria. The liver was washed several times with ice-cold saline solution. Ten percent of the liver homogenate was prepared using ice-cold potassium chloride $(\mathrm{KCl})(0.15 \mathrm{M})$ in a blender. Lipid peroxidation was initiated in $1 \mathrm{ml}$ of tissue homogenate mixed with various concentrations of the ethanol extract $(20,40,60,80$ and $100 \mu \mathrm{g} / \mathrm{ml})$. This was followed by adding $0.1 \mathrm{ml}$ of ferric sulphate $(2.5 \mathrm{mM}), 0.1 \mathrm{ml}$ of ascorbate $(100 \mathrm{mM})$ and $0.1 \mathrm{ml}$ of $\mathrm{KH}_{3} \mathrm{PO}_{4}(10 \mathrm{mM})$. The volume was made up to $3 \mathrm{ml}$ with distilled water and incubated at $37{ }^{\circ} \mathrm{C}$ for one hour. One $\mathrm{ml}$, each of 5 $\%$ trichloroacetic acid (TCA) and $0.6 \%$ thiobarbituric acid (TBA) was then added to the reaction mixture and the tubes boiled for 30 minutes in a water bath. The tubes were centrifuged at $3500 \mathrm{rpm}$ for 10 minutes. The extent of inhibition of lipid peroxidation was evaluated by the estimation of thiobarbituric acid reactive substances (TBARS) level by measuring the absorbance at $532 \mathrm{~nm}$. The lipid peroxidation inhibition percentage was calculated by using the formula below;

$$
\text { Inhibition } \%=\frac{\left[\mathrm{A}_{\text {control }}-\mathrm{A}_{\text {test }}\right]}{\mathrm{A}_{\text {control }}} \times 100
$$

Where,

$\mathrm{A}_{\text {control }}=$ Absorbance of control

$\mathrm{A}_{\mathrm{test}}=$ Absorbance in the presence of the extracts

The experiments were repeated in triplicates. $\alpha$ - Tocopherol was used as standard antioxidant.

\section{DPPH (2, 2-diphenyl-1-picryl hydroxyl) radical scavenging assay}

The radical scavenging activity of the crude ethanol extract and fractions of $A$. barbadensis root against the DPPH radical (Sigma-Aldrich) was determined by a slightly modified method using UV (Chidambara Murthy et al., 2002; Leong and Shui, 2002). Concentrations of $20,40,60,80$ and $100 \mathrm{ug} / \mathrm{ml}$ of the crude extract and Vitamin $\mathrm{C}$ were prepared in methanol (Analytical grade). One $\mathrm{ml}$ of the extract was placed in a test tube, followed by $2 \mathrm{ml}$ of $0.1 \mathrm{mM}$ DPPH in methanol. A control solution was prepared containing the same amount of DPPH and methanol. This procedure was similarly conducted to determine the DPPH scavenging activity of the various fractions (chloroform, ethyl acetate and aqueous). The radical scavenging activity was calculated using the following formula;

\section{$\%$ inhibition $=\left[\mathrm{A}_{b}-\mathrm{A}_{\mathrm{a}}\right] / \mathrm{A}_{\mathrm{b}} \mathrm{X} 100$}

Where,

$\mathrm{A}_{\mathrm{b}}=$ the absorbance of the blank sample

$A_{a}=$ the absorbance of the extract and fractions

\section{Ferric reducing power assay}

The previously outlined method by Kumar $\boldsymbol{e t}$ al. (2005) was used in assessing the ferric reducing power of the samples. This was determined by mixing various concentrations of the crude extract, fractions and standard ascorbic acid solutions $(20,40,60,80$ and $100 \mu \mathrm{g} / \mathrm{ml})$ in $1 \mathrm{ml}$ of methanol with phosphate buffer $(2.5 \mathrm{ml}$, $0.2 \mathrm{M}$ at $\mathrm{pH}$ 6.6) and potassium ferricyanide $\mathrm{K}_{3}\left[\mathrm{Fe}(\mathrm{CN})_{6}\right](2.5 \mathrm{ml}, 1 \%$. The 
mixture was incubated at $50{ }^{0} \mathrm{C}$ for 20 minutes. Then $2.5 \mathrm{ml}$ of $10 \%$ trichloroacetic acid (TCA) was added to the mixture which was centrifuged at $3000 \mathrm{rpm}$ for 10 minutes at room temperature. An aliquot of $2.5 \mathrm{ml}$ of the supernatant was mixed with $2.5 \mathrm{ml}$ distilled water and ferric chloride $\left(\mathrm{FeCl}_{3}\right)$ $(0.5 \mathrm{ml}, 0.1 \%)$ and the absorbance of the reaction mixture was measured at 700 $\mathrm{nm}$ to detect increased reducing power. All the tests were performed in triplicate.

\section{Phytochemical and nutritional analysis}

The qualitative phytochemical screening of the crude ethanol extract and fractions was carried out to determine the different metabolites (glycosides, cardiac glycosides, saponins, flavonoids, phenolic, tannins, phlobatannins, terpenoids, alkaloids, steroids, polysaccharides and reducing sugars) using the methods described by Sofowora (1993), Trease and Evans (1996). The tota phenolic and flavonoid content was determined using the method of Lin (2007) while the saponin content was done using the method of Obadoni and Ochuko (2002); Ejikeme et al. (2014). The alkaloidal content was determined using the method of Harborne et al. (1973). The proximate analysis (gross chemica composition) was determined by the recommended method of Horwitz and Latimer (2000). The determined six food categories were moisture content, ash content, crude oil, crude fibre, crude protein and nitrogen free extract.

For the mineral element's composition, a weighed aliquot of $5 \mathrm{~g}$ of the powdered root was ashed at $550^{\circ} \mathrm{C}$ in the Muffle furnace for 5 hours and the residue dissolved in $100 \mathrm{ml}$ deionized water. Standard solutions of the minerals were prepared and used to calibrate the atomic absorption spectrophotometer (AAS) (model 969AA, Unicam Series) using acetylene-air flame at specific wavelengths. Aliquots of the ash solutions were injected into the AAS and from the standard curve the various concentrations were obtained.

\section{Cytotoxic and genotoxic Study}

\section{Allium cepa assay}

The relatively same sized purple variety of onion bulbs were obtained commercially from a local market in Benin City, Edo State, Nigeria. The bulbs were stored under dry and well aerated condition for three weeks before use to prevent rot and enhance viability. The outer scaly leaves of the onion bulbs were carefully removed with hand while the dried roots were shaved off with a sharp razor blade to expose the fresh meristematic tissues. The bulbs were placed into freshly obtained distilled water to protect the primordial cell from drying off Mouldy bulbs and those with shooting green leaves were discarded. The macroscopic evaluation (root growth inhibition) and microscopic analysis (induction of chromosomal aberrations) were subsequently done Photomicrographs of the root tip cells were taken using an Olympus model microscope with a 5 mega pixel digital microscopic eyepiece camera. The standard procedures earlier described by Rank and Nielsen (1994); Olorunfemi et al. (2011) was adopted for this bioassay with the under listed parameters determined as displayed in the formulas below.

Percentage(\%) root growth of control

$$
=\frac{\text { overall mean root length of test solution }}{\text { overall mean root length of control }} \times 100
$$

Mitotic index was computed by determining the mitotic cell frequency at the tip

$\frac{\text { Number of dividing cells }}{\text { Total number of cells counted }} \times 100$

The mitotic inhibition was determined using the following formula:

$$
\frac{\text { Mitotic index in control - Mitotic index in treatment }}{\text { Mitotic index in control }} \times 100
$$

Frequency of Chromosomal aberration:

$$
\frac{\text { Number of Aberrant cells }}{\text { Total number of cells counted }} \times 100
$$

\section{Sorghum bicolor assay}

The growth inhibitory effects of the ethanol extract of $A$. barbadensis was carried out following the method described by Fajana (2013). Seeds of Sorghum bicolor (Guinea corn) were purchased locally in Edo State, Nigeria. A simple viability test was carried out by placing a handful of the seeds in distilled water. The viability of the seeds was determined by their ability to sink in water. Those that remained submerged in water were removed and air dried for use while those which floated were discarded. The viable seeds were sterilized with $96 \%$ ethanol for 1 minute and then rinsed with distilled water. The, $10 \mathrm{ml}$ different concentrations $(5,10,15,20,25$ and $30 \mathrm{mg} / \mathrm{ml})$ of the ethanol extract containing $3.3 \%$ tween 80 in water were poured into $9 \mathrm{~cm}$ full Petri dishes lined with cotton wool and filter paper (Whatman No 1). Twenty (20) viable seeds were spread on each and incubated in the dark. The lengths $(\mathrm{mm})$ of the radicles emerging from the seeds were taken at 24, 48, 72, and 96 hours. The control seeds were only treated with $3.3 \%$ Tween 80 in distilled water containing no extracts. The experiments were carried out in triplicates

\section{Statistical analysis}

Data are shown as mean \pm SEM and mean \pm SD of the corresponding replicates. One Way ANOVA was done where applicable as well as a Duncan's multiple range test to analyse differences among different means and the interaction between the variables using SPSS 15.0 computer software package. Differences at $P<0.05$ or $P<0.01$ were considered statistically significant.

\section{RESULTS}

\section{Percentage yield of extract and fractions}

Two kilograms of the powdered root plant material yielded $124.65 \mathrm{~g}(6.23 \%)$ of the ethanol extract. The fractionation of $40 \mathrm{~g}$ of the ethanol extract gave various yields of $10.96 \mathrm{~g}(27.4 \%), 2.69 \mathrm{~g}(6.73 \%)$ and $22.89 \mathrm{~g}(57.23 \%)$ corresponding to the chloroform, ethyl acetate and aqueous fractions respectively (Tab1)

Table 1 Percentage extract/fractions yield of A. barbadensis root

\begin{tabular}{lc}
\hline Extract/ Fractions & Yield in $(\%)$ and $(\mathbf{g})$ \\
\hline Ethanolic extract & $6.23 \%(124.65 \mathrm{~g})$ \\
Aqueous fraction & $57.23 \%(22.89 \mathrm{~g})$ \\
Chloroform fraction & $27.4 \%(10.96 \mathrm{~g})$ \\
Ethyl acetate fraction & $6.73 \%(2.69 \mathrm{~g})$ \\
\hline
\end{tabular}

\section{Antimicrobial effect of $A$. barbadensis root extract on test organisms}

The susceptibility of the test organisms to the ethanolic extract of $A$. barbadensi root is shown in Tables $2-3$. The tested concentrations of the extract of AB had a certain degree of inhibitory activity against the tested organisms with the highest zone of inhibition of $25.00 \pm 1.73 \mathrm{~mm}$ recorded against Staphylococcus saprophyticus at a concentration of $50 \mathrm{mg} / \mathrm{ml}$ ( Tab 2). It was observed that the extract had a MIC of $6.25 \mathrm{mg} / \mathrm{ml}$ against $E$. coli and $S$. saprophyticus while the MIC was $12.5 \mathrm{mg} / \mathrm{ml}$ against $P$. mirabilis, $P$. aeruginosa and $K$. pneumoniae. The extract had the same MBC value of $12.5 \mathrm{mg} / \mathrm{ml}$ against the tested organisms (Tab 3). The positive control, chloramphenicol was active against all test organisms but significantly at the highest concentration of $50 \mathrm{mg} / \mathrm{ml}$. The commercial antibiotic (chloramphenicol) was most active against Staphylococcus saprophyticus with an inhibitory diameter of $24 \mathrm{~mm}$ and least active against $E$. coli and P. aeruginosa with no measurable zone of inhibition (Tab 4).

Table 2 Effect of various concentrations of the ethanolic root extract of Aloe barbadensis on test organisms

Test organisms Concentrations of Extract $(\mathrm{mg} / \mathrm{ml})$

$12.5 \quad 25 \quad 50$

\begin{tabular}{llll} 
Escherichia coli & $8.00 \pm 0.58$ & $12.67 \pm 0.88$ & $16.00 \pm 1.00$ \\
Klebsiella pneumoniae & $4.67 \pm 0.88$ & $6.67 \pm 0.88$ & $15.00 \pm 2.00$ \\
Proteus mirabilis & $3.00 \pm 0.58$ & $4.33 \pm 0.88$ & $12.00 \pm 1.00$ \\
Pseudomonas aeruginosa & $4.33 \pm 0.67$ & $8.00 \pm 0.58$ & $14.67 \pm 1.45$ \\
Staphylococcus saprophyticu & $9.70 \pm 0.88$ & $13.33 \pm 1.20$ & $25.00 \pm 1.73$ \\
\hline
\end{tabular}

Values are mean \pm SEM (zone of inhibition in $\mathrm{mm}$ ); $\mathrm{n}=3$

Table 3 Antibacterial activity (MIC and MBC) of the ethanol extract of $A$. barbadensis root

\begin{tabular}{lcc}
\hline Isolates & MIC $(\mathbf{m g} / \mathbf{m l})$ & MBC $(\mathbf{m g} / \mathbf{m l})$ \\
\hline Escherichia coli & 6.25 & 12.5 \\
Klebsiolla & 12.5 & 12.5 \\
pneur & & \\
Prote & 12.5 & 12.5 \\
Pseuaomonas & 12.5 & 12.5 \\
aeruginosa & & \\
Staphylococcus & 6.25 & 12.5 \\
saprophyticus & & \\
\hline
\end{tabular}


Table 4 Antibiotic sensitivity of the test organisms with growth inhibitory zones

\begin{tabular}{|c|c|c|c|}
\hline \multirow{2}{*}{ Organisms } & \multicolumn{3}{|c|}{ Chloramphenicol } \\
\hline & $12.5 \mathrm{mg} / \mathrm{ml}$ & $25 \mathrm{mg} / \mathrm{ml}$ & $50 \mathrm{mg} / \mathrm{ml}$ \\
\hline Escherichia coli & NMZI & NMZI & $10.06 \pm 0.05$ \\
\hline $\begin{array}{l}\text { Klebsiella } \\
\text { pneumoniae }\end{array}$ & $4.00 \pm 0.04$ & $10.02 \pm 0.07$ & $18.00 \pm 0.03$ \\
\hline Proteus mirabilis & NMZI & $10.09 \pm 0.03$ & $16.00 \pm 0.09$ \\
\hline $\begin{array}{l}\text { Pseudomonas } \\
\text { aeruginosa }\end{array}$ & NMZI & NMZI & $12.00 \pm 0.02$ \\
\hline $\begin{array}{l}\text { Staphylococcus } \\
\text { saprophyticus }\end{array}$ & $10.05 \pm 0.06$ & $15.00 \pm 0.03$ & $24.00 \pm 0.02$ \\
\hline
\end{tabular}

\section{Antioxidant activities of $A$. barbadensis root extract}

\section{Lipid peroxide scavenging activity of $A$. barbadensis root extracts}

The result of the lipid peroxide scavenging activity of the extract and fractions are presented in Figure 1. It was noticed that the ethanolic extract had a concentration-dependent activity. The chloroform fraction had a maximum inhibition of $48.28 \pm 0.34 \%$, followed by the crude ethanolic extract with $46.57 \pm$ $0.69 \%$, ethyl acetate had an inhibition zone of $30.58 \pm 1.04 \%$. The aqueous fraction had the least inhibition of $30.07 \pm 1.89 \%$. This scavenging activity happened at the same concentration of $100 \mu \mathrm{g} / \mathrm{ml}$. The standard positive control, $\alpha$-tocopherol had inhibition of $97.33 \pm 0.54 \%$ at $100 \mu \mathrm{g} / \mathrm{ml}$ (Figure 1).

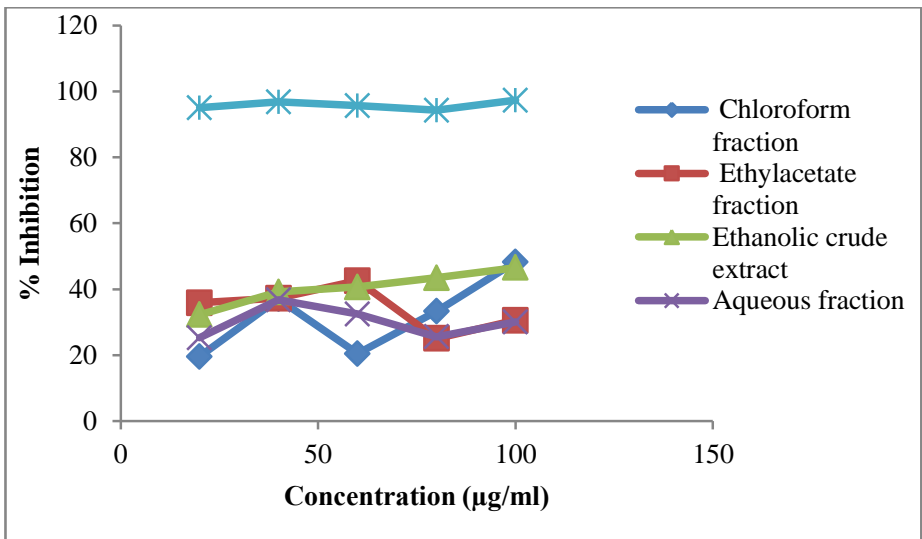

Figure 1 Lipid peroxide free radical scavenging activity of the crude ethanolic extract and fractions of A. barbadensis root

\section{DPPH scavenging activity of $A$. barbadensis root extracts}

The ethyl acetate fraction had the highest free radical scavenging ability with a percentage inhibition of $82.2 \pm 0.44 \%$ at $100 \mu \mathrm{g} / \mathrm{ml}$ while the chloroform fraction had the lowest inhibition of $27.52 \pm 2.32 \%$ at the same concentration of $100 \mu \mathrm{g} / \mathrm{ml}$. The standard positive control (Vitamin C) had an inhibition percentage range of $93.39 \%$ to $94.72 \%$ (Figure 2).

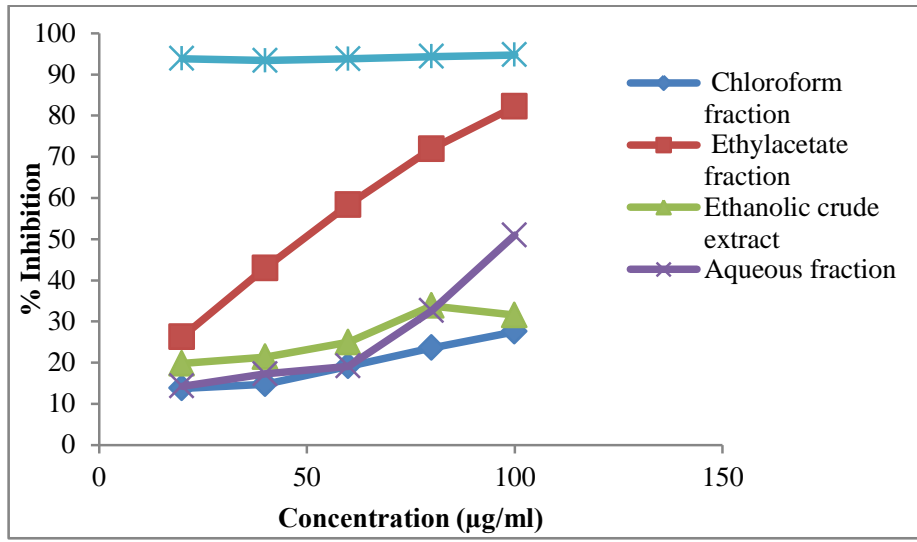

Figure 2 DPPH scavenging activities of crude ethanolic extract and fractions of A. barbadensis root with Vitamin C.

\section{Ferric reducing power of $A$. barbadensis root extracts}

The ferric reducing power potential of the ethanolic extract and fractions are shown in Figure 3. The highest reducing power activity was observed in the ethyl acetate fraction, with an average absorbance range of $0.145 \pm 0.01$ to $0.36 \pm 0.00$ $\mathrm{nm}$. (Figure 3). The positive control (Vitamin C) had a concentration-dependent ferric reducing power within an absorbance range of 0.962 to $1.513 \mathrm{~nm}$.

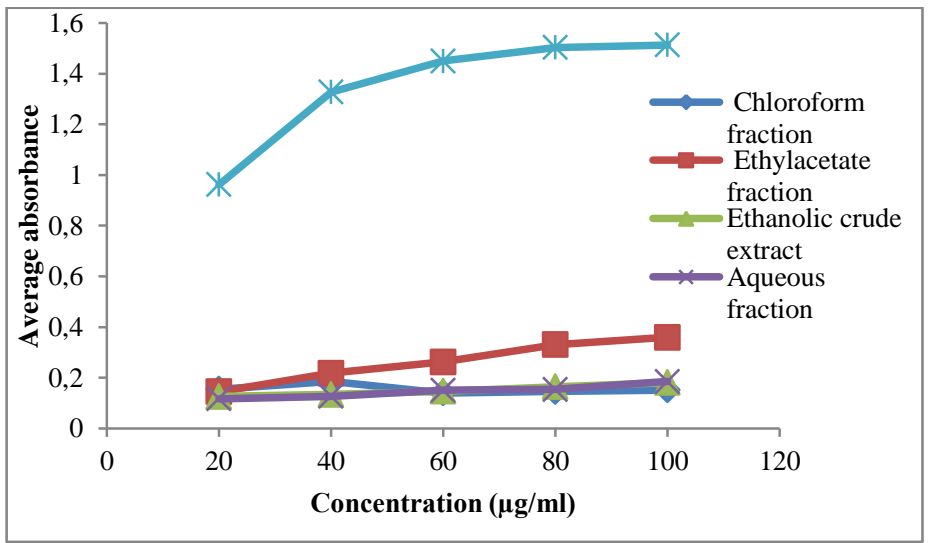

Figure 3 Ferric reducing powers of the crude ethanolic extract and fractions of $A$. barbadensis root

Preliminary phytochemistry and nutritional attributes of $A$. barbadensis root extract

Qualitative phytochemistry of ethanol root extract of $A$. barbadensis and its fractions

The prefatory phytochemical screening of the crude ethanolic root extract and fractions (chloroform, ethyl acetate and aqueous) of A. barbadensis revealed the presence of condensed tannins, phenolic compounds, flavonoids, glycosides and reducing sugars in all the tested extracts. Saponins were absent only in the chloroform extract while terpenoids were present in the chloroform and ethyl acetate fractions only. Alkaloids were present in the ethanol extract and ethyl acetate fraction only. Steroids were only present in the ethyl acetate fraction (Tab $5)$.

Table 5 Qualitative phytochemical composition of the ethanol extract and fractions of A. barbadensis root

\begin{tabular}{|c|c|c|c|c|}
\hline \multirow[b]{2}{*}{ Phytochemicals } & \multirow[b]{2}{*}{ Ethanol extract } & \multicolumn{2}{|c|}{ Fractions } & \multirow[b]{2}{*}{ Aqueous } \\
\hline & & Chloroform & Ethyl acetate & \\
\hline Glycoside & +++ & ++ & + & ++ \\
\hline Cardiac glycoside & + & - & - & - \\
\hline Saponin & ++ & - & + & ++ \\
\hline Flavonoid & ++ & +++ & + & + \\
\hline Phenolic compound & ++ & ++ & ++ & + \\
\hline Hydrolysable tannin & - & - & - & - \\
\hline Condensed tannin & ++ & ++ & ++ & + \\
\hline Phlobatannins & + & - & - & - \\
\hline Terpenoid & - & ++ & ++ & - \\
\hline Alkaloid & + & - & + & - \\
\hline Polysaccharide/Starch & - & - & - & - \\
\hline Reducing sugar & +++ & ++ & ++ & ++ \\
\hline Steroids & - & - & + & - \\
\hline
\end{tabular}

Legends: +++ ; appreciable amount; + +: moderate amount; +: minute amount; -: not detected 
Quantitative analysis of $A$. barbadensis root.

The percentage total phenolic content was found to be highest $(2.12 \pm 0.003)$ quantitatively of the secondary metabolites determined, closely followed by saponins $(1.75 \pm 0.001)$. Alkaloids had the lowest concentration of $0.121 \pm$ $0.001 \%$ (Tab 6)

Table 6 Quantitative Composition of the ethanol extract of Aloe barbadensis root

\begin{tabular}{lc}
\hline Parameters & Composition (\%) \\
\hline Alkaloids & $0.12 \pm 0.001$ \\
Flavonoids & $1.21 \pm 0.002$ \\
Saponins & $1.75 \pm 0.001$ \\
Phenolics & $2.12 \pm 0.003$ \\
\hline
\end{tabular}

Values represent Mean \pm SEM of three (3) determinations.

\section{Proximate composition of $A$. barbadensis root}

The percentage composition on a dry weight basis presented in Table 7 indicated that the root of $A$. barbadensis contained a moderate amount of crude fibre $(30.05$ $\pm 2.33 \%$ ) and $24.66 \pm 1.89 \%$ nitrogen free extract.

Table 7 Proximate Composition of the root of Aloe barbadensis

\begin{tabular}{lc}
\hline Parameters & Composition (\%) \\
\hline Moisture Content & $10.23 \pm 0.04$ \\
Ash Content & $18.48 \pm 0.32$ \\
Crude Oil & $9.15 \pm 1.34$ \\
Crude Protein & $7.44 \pm 0.62$ \\
Crude Fibre & $30.05 \pm 2.33$ \\
Nitrogen Free Extract (NFE) & $24.66 \pm 1.89$ \\
\hline
\end{tabular}

Values represent Mean \pm Standard deviation of two (2) determinations on dry Weight basis.

\section{Mineral element composition of the root of $A$. barbadensis.}

The root extract was found to have a considerable concentration of iron (37.42 \pm $0.001 \mathrm{mg} / \mathrm{kg})$, sodium $(21.01 \pm 0.002 \mathrm{mg} / \mathrm{kg})$ and potassium $(15.14 \pm 0.001$ $\mathrm{mg} / \mathrm{kg})$ (Tab 8). The amount of zinc quantified was low $(0.02 \pm 0.003)$, while cadmium and lead were not detected.
Table 8 Minerals Composition of the root of Aloe barbadensis

\begin{tabular}{lc}
\hline Minerals & Concentration $(\mathbf{m g} / \mathbf{k g})$ \\
\hline Potassium & $15.14 \pm 0.001$ \\
Calcium & $3.12 \pm 0.003$ \\
Sodium & $21.01 \pm 0.002$ \\
Magnesium & $2.01 \pm 0.002$ \\
Iron & $37.42 \pm 0.001$ \\
Zinc & $0.02 \pm 0.003$ \\
Manganese & $0.10 \pm 0.001$ \\
Lead & $\mathrm{ND}$ \\
Cadmium & $\mathrm{ND}$ \\
\hline Legend: ND- Not Detected; Values represent Mean \pm SEM of three $(3)$
\end{tabular}

determinations on a dry weight basis.

Cytotoxic and genotoxic evaluation of $\mathrm{AB}$ root extract

Effect of $\mathrm{AB}$ root extract on root length and meristematic cells of Allium cepa

The highest growth rate (root length) was observed at $0.25 \mathrm{mg} / \mathrm{ml}$ with a root length of $1.74 \pm 0.05 \mathrm{~cm}$, while the lowest growth was observed at $1 \mathrm{mg} / \mathrm{ml}$ with a corresponding root length of $0.76 \pm 0.03 \mathrm{~cm}$ (Tab 9). The mitotic indices, types and numbers of aberrations of the different concentrations of the crude ethano extract of Aloe barbadensis root were also recorded in this study. It was observed that the mitotic index decreased with an increase in concentration of the extract (Table 10) while several chromosomal aberrations were induced in the Allium cepa root cells when exposed to the ethanol extract of A. barbadensis (Figure 4).

Table 9 Mean root length of Allium cepa exposed to crude ethanolic extract of $A$ barbadensis root

\begin{tabular}{lccc}
\hline $\begin{array}{l}\text { Concentrations } \\
\text { of extract } \\
(\mathbf{m g} / \mathbf{m l})\end{array}$ & $\begin{array}{c}\text { Number of } \\
\text { Roots }\end{array}$ & $\begin{array}{c}\text { Mean root length } \\
(\mathbf{c m})\end{array}$ & $\begin{array}{c}\text { \% Root Growth of } \\
\text { control }\end{array}$ \\
\hline Control & 100 & $3.11 \pm 0.07$ & 100.00 \\
$\mathbf{0 . 2 5}$ & 100 & $1.74 \pm 0.05$ & 55.95 \\
$\mathbf{0 . 5}$ & 90 & $1.15 \pm 0.05$ & 36.98 \\
$\mathbf{0 . 7 5}$ & 100 & $1.14 \pm 0.05$ & 36.66 \\
$\mathbf{1}$ & 93 & $0.76 \pm 0.03$ & 42.44 \\
\hline
\end{tabular}

Values are Mean \pm SEM of five replicates; Control - distilled water

Table 10 Cytological effects on Allium cepa root tip cells grown in various concentrations of ethanolic extract of Aloe barbadensis root

\begin{tabular}{|c|c|c|c|c|c|c|c|c|c|c|c|c|c|}
\hline 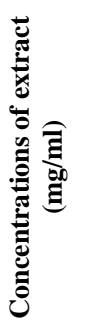 & 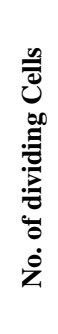 & 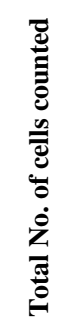 & 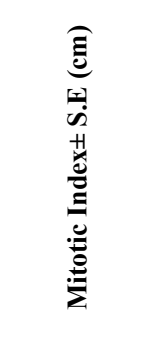 & 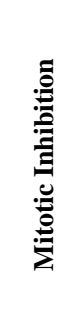 & 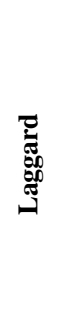 & 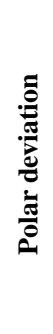 & 苞 & 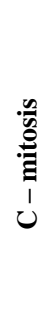 & 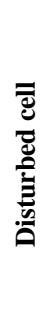 & $\underset{\vec{J}}{\vec{\Xi}}$ & 彰 & $\frac{\tilde{E}}{\stackrel{0}{0}}$ & 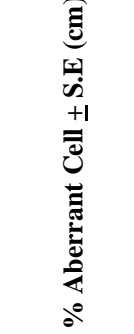 \\
\hline Control & 174 & 2113 & $8.63 \pm 0.38$ & 0.00 & 1 & & 2 & & & $\overline{1}$ & & $\overline{1}$ & $0.24 \pm 0.25$ \\
\hline 0.25 & 155 & 2043 & $7.40 \pm 0.42$ & 13.79 & 4 & 7 & 5 & 5 & 3 & 5 & & 5 & $1.66 \pm 0.46$ \\
\hline 0.50 & 137 & 2145 & $6.29 \pm 0.38$ & 27.11 & 6 & 6 & 9 & 4 & 4 & 8 & & 7 & $2.05 \pm 0.71$ \\
\hline 0.75 & 128 & 2118 & $6.04 \pm 0.43$ & 30.01 & 6 & 8 & 9 & 6 & 4 & 8 & 1 & 5 & $2.27 \pm 0.97$ \\
\hline 1 & 116 & 2045 & $7.36 \pm 0.34$ & 34.88 & 9 & 4 & 11 & 7 & 4 & 10 & 1 & 12 & $2.84 \pm 1.39$ \\
\hline
\end{tabular}




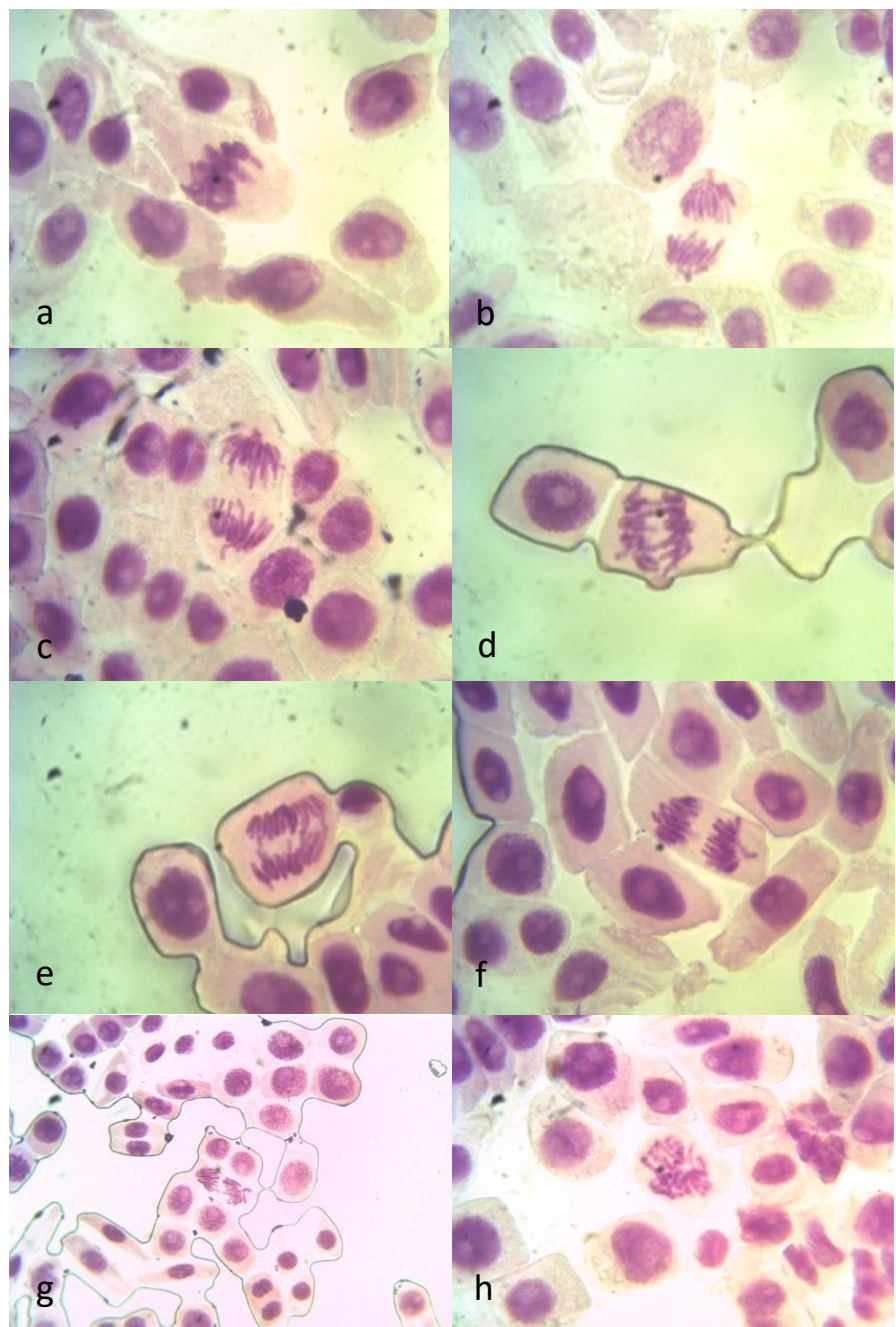

Figure 4 Chromosomal aberrations induced in Allium cepa root exposed to ethanol extract of A. barbadensis root (a) Vagrant + Polar deviation, (b) Sticky metaphase, (c) Vagrant cell on anaphase, (d) Multiple bridges, (e) Bridge, (f) Vagrant, (g) Polar deviation, (h) C- mitosis

\section{Effect of AB root extract on root length of Sorghum bicolor (guinea corn)}

A significant reduction $(P<0.01)$ in the radicle length of Sorghum bicolor when exposed to the ethanolic extract of $A$. barbadensis during the entire period of the study was noticed (Tab 11). After $24 \mathrm{hr}$, a significant reduction in the average radicle length $(0.13 \pm 0.09 \mathrm{~mm})$ of the seeds of guinea corn was recorded at the 20 $\mathrm{mg} / \mathrm{ml}$ concentration of the extract compared to an average length of $4.17 \pm 0.42$ $\mathrm{mm}$ observed in the control. The effect of the extract on the radicle length of S.bicolor at all tested concentrations after 24 and $48 \mathrm{hrs}$ (except $5 \mathrm{mg} / \mathrm{ml}$ ) were not significantly different from each other but differed significantly $(P<0.01)$ from the control.

\section{DISCUSSION}

\section{Antimicrobial potential}

Infectious diseases, according to Okigbo and Ajalie (2005), are responsible for over one percent of deaths occurring in tropical countries. Infertility is one ailment that has been linked to these infections and accounts for two-thirds of the recorded infertility cases in Nigeria (Okonofua et al., 1995). Similarly, polymicrobial infections have been linked to many cases of erectile dysfunction (Momoh et al., 2011). In this study, ethanolic root extract of $A$. barbadensis was active against the Gram-positive and Gram-negative bacterial species isolated from the semen samples with a zone of inhibition of $\geq 10 \mathrm{~mm}$ (Andrews, 2005; Usman et al., 2005). The inhibitory activity of the extract was found to be concentration-dependent (Tab 2). The isolated bacterial species from this study were similar to species isolated from earlier work (Ekhaise and Richard, 2008; Ibadin and Ibeh, 2008; Komolafe and Awoniyi, 2013). This probably reflects the prevalence of these bacterial species associated with male infertility due to their ability to cause polymicrobial infections. The ethanolic extract of $A$. barbadensis at $50 \mathrm{mg} / \mathrm{ml}$ had the highest inhibitory activity against the isolated organisms. It is noteworthy that the extract suppressed the growth of the isolated Gram-negative bacterial species. This indicated a very good antimicrobial property of the extract which agrees with the report of Ashafa et al. (2008) on the ability of the stem extracts of Felicia muricata to inhibit all Gram-negative bacterial strains tested. Of the isolated bacterial species, E. coli, P. aeruginosa and $S$. saprophyticus had lower tolerance to the extract when compared to the control drug, at $50 \mathrm{mg} / \mathrm{ml}$ ( Tab 2). The MIC and MBC values of the extract (Tab 3 ) suggested that the tested organisms had low resistance. According to the MIC result, the extract was most active against $E$. coli and $S$. saprophyticus with the same MIC value of $6.25 \mathrm{mg} / \mathrm{ml}$ compared to a MIC of $12.5 \mathrm{mg} / \mathrm{ml}$ obtained for the other organisms. The extract had bactericidal activity against all the tested bacteria with an MBC value of $12.5 \mathrm{mg} / \mathrm{ml}$ for all the isolated species. It can, therefore, be inferred that the bactericidal activity of the extract against the isolated organism may prevent the inhibition of spermatogenesis and sperm function impairment in infertile males (Ibadin and Ibeh, 2008).

\section{Antioxidant study}

Antioxidants are chemical substances used to prevent human diseases and disorders, including male infertility. They scavenge or inhibit the production of free radicals (reactive oxygen species), which are very toxic to different forms of biological molecules (DNA, lipids, protein and carbohydrates) (Ashafa $\boldsymbol{e t}$ al., 2010; Raghuveer and Vyas, 2010). In the antioxidant assays, the ethanol extract and fractions of $A$. barbadensis exhibited strong scavenging activity against the free radicals. Prasad and Ramakrishnan (2012) reported that the exposure of unsaturated lipids in cell membranes and liver tissues to reactive oxygen species (ROS) make them very susceptible to peroxidation. The crude extract and fractions from the results obtained from this assay displayed a significant antiperoxidant effect (Figure 1). The chloroform fraction had the highest scavenging/ inhibitory activity of $48.28 \pm 0.34 \%$, followed by the crude ethanolic extract $(46.57 \pm 0.69 \%)$. The antiperoxidant effect of the ethanolic extract which was observed to be concentration dependent was similar to the findings of a previous study elsewhere (Prasad and Ramakrishnan, 2012) where the lipid peroxide radical scavenging potential of Rumex vesicarius was investigated. The inhibitory lipid peroxidation potential of the extract and fractions reflects their ability to probably reduce the risk factors associated with the induction and development of atherosclerosis (Godwin and Prabhu, 2006); slow down the aging process and boost immune responses (Prasad and Ramakrishnan, 2012) The lipid peroxidation inhibitory capacity of the extract and fractions is also very remarkable as it can be linked to the ability of the plant to prevent peroxidative damage to the plasma membrane of the sperm and loss of DNA structural integrity. This also ensures prevention of cell mortality and enhanced fertility (Lombardo et al., 2011). The potent lipid peroxidation inhibitory effect of the extract and fractions can also be an indication that the plant may prevent loss of sperm membrane fluidity, which in turn improves sperm motility and sperm oocyte fusion (Raghuveer and Vyas, 2010). The lipid peroxidation inhibition capacity in this study supports the use of the plant in treating reproductive disorders/ailments, as previously reported by Erhabor and Idu (2017). For the DPPH assay (Figure 2), the extract and fractions had a high scavenging activity against the reactive oxygen species produced.

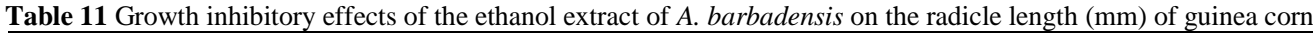

\begin{tabular}{|c|c|c|c|c|c|}
\hline Groups & 24hrs & 48hrs & 72hrs & 96hrs & P-Value \\
\hline Control & $4.17^{\mathrm{a} \#} \pm 0.42$ & $16.63^{\text {a\#\# }} \pm 2.8$ & $22.83^{\mathrm{a} \# \# \#} \pm 0.08$ & 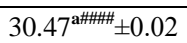 & $* * \mathrm{P}<0.01$ \\
\hline $5 \mathrm{mg} / \mathrm{ml}$ & $0.30^{\mathrm{b \#}} \pm 0.06$ & $7.57^{\mathrm{c} \# \#} \pm 0.88$ & $2.63^{\mathrm{c \# \#} \pm 0.01}$ & 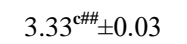 & $* \mathrm{P}<0.05$ \\
\hline $15 \mathrm{mg} / \mathrm{ml}$ & $0.33^{\mathrm{b \#}} \pm 0.09$ & $1.23^{\mathrm{b \# \#}} \pm 0.27$ & 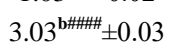 & 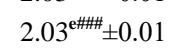 & $* * \mathrm{P}<0.01$ \\
\hline $20 \mathrm{mg} / \mathrm{ml}$ & $0.13^{\mathrm{b} \#} \pm 0.09$ & $0.27^{\mathrm{b} \#} \pm 0.03$ & $1.41^{\mathrm{d} \# \# \pm 0.01}$ & $2.50^{\mathrm{d} \# \# \# \pm 0.02}$ & $* * \mathrm{P}<0.01$ \\
\hline $25 \mathrm{mg} / \mathrm{ml}$ & $0.80^{\mathrm{b \#}} \pm 0.26$ & $1.63^{\mathrm{b \#}} \pm 0.9$ & $3.11^{\mathrm{b \# \#}} \pm 0.01$ & 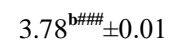 & $* * \mathrm{P}<0.01$ \\
\hline
\end{tabular}

Values are mean \pm SEM; $\mathrm{n}=20$, Note: $* * P<0.01$-Highly Significant, $* P<0.05$-Significant, $P>0.05$-Not Significant

Different superscript letters (in columns) shows that the mean is significant from others.

Different ${ }^{\#}$ (in rows) shows there is a significant difference across the sampled means across the hours. 
The ethyl acetate fraction had the highest activity compared to the crude extract and other fractions. The concentration-dependent scavenging activity of the ethanol extract until the penultimate concentration $(80 \mu \mathrm{g} / \mathrm{ml})$ was observed. It was also noticed that the fractions had a concentration-dependent scavenging activity. The ability of the extract to inhibit the oxidation of DPPH implies that it can donate protons and scavenge other stable radicals. This agrees with the findings of Falodun and Irabor (2008) where a concentration-dependent scavenging ability of the methanol extract of Calliandria surinamensis was observed against the DPPH radical. Within the concentrations used in the ferric reducing power assay, the ethanolic extract, fractions (ethyl acetate and aqueous) and Vitamin C (positive control) exhibited a reducing power that increased as the concentration increased (Figure 3). This reducing power may be attributed to the ability of the extract and fractions to donate hydrogen that can react with reactive oxygen species to stabilize and end radical chain reactions (Sudha et al., 2011) It may also be due to hydrophilic polyphenolic compounds in the extract and fractions (Okolie et al., 2011; Yen et al., 1993), which have been implicated as being effective hydrogen donors (good oxidants). These findings are in sync with previous reports (Al-Fartosy, 2011; Okolie et al., 2011; Sudha et al., 2011 were the reductive capacities (antioxidant potential) of the ethyl acetate extract of pepino fruit; ethanol root extract of Rauwolfia vomitoria and methanol extract of Inula graveolus increased proportionally to their respective concentrations.

\section{Phytochemical and nutritional composition of $\mathrm{AB}$ root}

Investigations into the phytochemical constituents of the ethanol extract and its fractions revealed that glycosides, flavonoids, phenols, tannins and reducing sugars were present in the extract and fractions (Tab 5). The saponin content of the crude extract may have been responsible for the earlier reported aphrodisiac property of A. barbadensis root (Erhabor and Idu, 2017). This is because saponin has been previously postulated as a possible constituent responsible for the aphrodisiac property of Tribulus terrestris. It has also been found to increase testosterone in the body by raising the concentrations of luteinizing hormone which helps to sustain testosterone concentrations (Gauthaman, et al., 2002) Also, the aphrodisiac potential of clove (Syzygium aromaticum) has been attributed to the presence of sterols or phenolic compounds from an earlier study (Ahmad et al., 2004). The crude extract from the phytochemical results contained phenols but lacked sterols which were present only in the ethyl acetate fraction. Alkaloids have been reported to increase the dilation of blood vessels in the male sex organ (Zamblé et al., 2008) and are said to be one of the mechanisms of action through which aphrodisiac substances act. The ethanol extract of A. barbadensis was also found to contain an alkaloid, which can be linked to the increased blood flow noticed in the histological studies (Erhabor, 2015). Therefore, phenols, alkaloids and saponins may synergistically or individually be responsible for the aphrodisiac activity of the ethanolic extract of A. barbadensis. This agrees with the assertion that phytoconstituents potentiates erection and prolong ejaculatory latency in male rats (Muanya and Odukoya, 2008; Sumalatha et al., 2010; Yakubu et al., 2005). The occurrence of phenol in the extract may be responsible for its probable cytotoxic and antiproliferative properties. This can be inferred from earlier studies adducing the cytotoxic and antiproliferative activity of phenols against melanocytes cell lines (Ayinde and Agbakwuru, 2010). Hour et al. (1980) also reported that saponins and flavonoids had antitumor and anticancer properties and as a result, their presence in A. barbadensis could be linked to its relatively toxic effect on cells. Again, phenols and flavonoids have been suggested to be responsible for the radical scavenging activities of most drugs (Falodun et al., 2011). Therefore, it is possible that these secondary metabolites can be responsible for the antioxidant property of the ethanolic extract and fractions of $A$ barbadensis. However, the tannins in the root extract of A. barbadensis may cause its antimicrobial activity as earlier reported by Sodipo (1991). Flavonoids which have also been reported to have antimicrobial properties by Yebpella et al. (2011) are one of the chemical constituents in the extract of $A$. barbadensis. It is pertinent to note that the percentage composition of alkaloids, flavonoids and phenols $(0.12 \% ; 1.21 \%$ and $2.12 \%$ were lower than those recorded for the leaves of Cymbopogon citratus which had concentrations of $1.38 \%, 4.76 \%$ and $3.58 \%$ respectively. The saponin content $(1.75 \%)$ was, however greater than that of $C$. citratus leaves $(1.25 \%)$ (Uraku et al., 2016).

The proximate constituents of a plant indicate nutrients available in the plant. The nitrogen free extract (NFE) in A. barbadensis root (Tab 7) may have provided the required energy for cellular activities such as arousal of the penis when metabolized in the body as reported by Odesanmi et al. (2012) on the nutritional prospect of Microdesmis keayana. The NFE of A. barbadensis was found to be lower than that of Acorous calamus (75.03\%) as reported by Barua et al. (2015) The root of A. barbadensis also has protein which may form a pool for amino acids such as arginine which have been suggested to potentiate the aphrodisiac properties of medicinal plants (Sumalatha et al., 2010). The protein value from this present study was found to be lower than that reported by Kibar and Temel (2016); Kibar and Kibar (2017) for some wild edible plants. The moisture and ash contents are two values that can show the stability, quality and purity of a powdered crude drug. The moisture and ash contents of A. barbadensis root (Table 7) were relatively high when compared to that of Microdesmis keayana root (Odesanmi et al., 2012). It was also observed that the ash content of $A$. barbadensis root (18.48\%) was higher than that of C. citratus leaves $(7.15 \%)$ as reported by Uraku et al. (2016). Interestingly, A. barbadensis root collected from the wild was also found to have higher ash content than the values reported by Kibar and Temel (2016); Kibar and Kibar (2017) for some wild edible plant species. The high values can be linked to its ability to store water for a long time, being a drought-resistant plant.

Micronutrients play vital roles in metabolism and enzymatic reactions when they function as co-factors and co-enzymes. The magnesium concentration in the roo sample of A. barbadensis (Tab 8) can be described as low $(2.01 \pm 0.002 \mathrm{mg} / \mathrm{kg})$ when compared to that of Microdesmis keayana root (458.8 $\pm 5.44 \mathrm{ppm})$ However, magnesium is useful in the biosynthesis of sex hormones such as androgen, oestrogens and neurotransmitters (dopamine and norepinephrine which aid in sex modulation) (Odesanmi et al., 2012). Potassium which function as a major cation of intercellular fluid, regulate the electrode potential and concentration of aldosterone and cell membrane permeability as reported by Robert et al. (2003) and was detected in moderate amount $(15.14 \pm 0.001 \mathrm{mg} / \mathrm{kg})$ in the root of A. barbadensis. The concentrations of iron $(37.24 \pm 0.001 \mathrm{mg} / \mathrm{kg})$ and sodium $(21.01 \pm 0.002 \mathrm{mg} / \mathrm{kg})$ were higher than those of Microdesmis keayana which recorded values of $5.62 \pm 0.48 \mathrm{ppm}$ and $5.68 \pm 0.25 \mathrm{ppm}$. The quantification of calcium in the root of A. barbadensis was very important as it helps in protecting the structural integrity of the skeleton and provides energy for contraction via a complex reaction involving vital enzymes regulating metabolism at the intermediary level (Breslau, 1991). Another mineral element, zinc, functions in boosting the immune system and is necessary for the effective synthesis of testosterone and as such can prevent or be used in managing male infertility (Odesanmi $\boldsymbol{e t}$ al., 2012). The presence of zinc maybe responsible for the ability of the plant to boost the immune system and increased testosterone which supports the aphrodisiac use of the plant.

\section{Cytotoxic and genetoxic effects of $A$. barbadensis root}

Earlier report by Grant (1994) reported the ability of the meristematic cells of Allium cepa root tip to interact with mutagenic substances and as a result, these are used to detect the cytotoxic and genotoxic effects of harmful chemicals. The macroscopic evaluation of the A. cepa root showed that the extract at all concentrations decreased the root growth of the tested onion bulbs when compared to the control (distilled water) (Tab 9). This finding implied that the extract may be relatively toxic and can inhibit tumour-producing cells. From an earlier study, inhibition of the root growth of $A$. cepa suggests a reduction in the number of dividing cells (Olorunfemi et al., 2011), which reflects the mitodepressive effect of the extract on the ability of $A$. cepa cells to divide. Thus, the extract may have the ability to inhibit the synthesis of DNA and nucleus proteins, a process that had been reported with extract of other plants (Stephen, 1980; Timothy et al., 2014). These results support report in this study where the effect of the extract inhibited the radicle growth of Sorghum bicolor seeds.

Following the previous report by Smaka-Kincl $\boldsymbol{e t}$ al. (1996), a decrease in the rate of mitotic index is one acceptable measure for determining the cytotoxic effect of harmful substances on all living organisms. The ethanol extract of $A$. barbadensis showed a concentration dependent decrease in mitotic index (MI) which implies a cytotoxic effect (Tab 10). This is consistent with an earlier report by Timothy $\boldsymbol{e t}$ al. (2014) where the extract of Icacina trichantha decreased the MI of A. cepa root cells. Also, Olorunfemi et al. (2014) stated that chromosomal aberration and abnormalities are useful parameters for assessing genotoxic activity of a substance. These aberrations include sticky chromosomes, vagrant chromosomes, bridges, polar deviations and spindle disturbance. It was observed that the extract induced certain levels of chromosomal aberrations at all the tested concentrations (Figure 4). This concentration-dependent activity of the extract on the chromosomes of the A. cepa root cells implies a cyto-genotoxic effect of the extract. Therefore, it can be inferred that the extract has the functional therapeutic ability to destroy cancerous cells (Dahof, 1983). This finding also agrees with previous studies by Timothy et al., (2014) were the cyto-genotoxic activity of the leaf extract of Icacina trichantha on A. cepa root cells was tested.

It has been reported that meristematic tissues of seeds can rapidly multiply when exposed to favourable conditions. The level of proliferation is reflected in an increase in the radicle length of the seeds during a defined period ( $96 \mathrm{hrs}$ ) (Ikpefan et al., 2013). Also, germination inhibition and subsequent growth of the Sorghum spp radicle have been suggested as a measure to determine the herbicidal potential of a plant extract or its ability to induce dormancy and retard the growth of tumor-producing cells (Sogbaike et al., 2002). Administration of the ethanol extract of $A$. barbadensis at all concentrations and within the tested period significantly $(p<0.01)$ inhibited the growth of Sorghum bicolor radicle (Tab 11). The extract displayed a concentration-dependent reduction in the radicle length of $S$. bicolor seeds when compared to the control. The extract of $A$. barbadensis root exerted the greatest significant $(p<0.01)$ inhibitory effect against the growth of the $S$. bicolor radicle at $20 \mathrm{mg} / \mathrm{ml}$. The result implies that the extract possessed an anti-proliferative activity which suggests that it can be used to retard the growth of cells that produce tumours. This finding agrees with earlier reports by Fajana (2013), Ikpefan et al. (2013) on the growth inhibitory activity of the methanol extract of Tridax procumbens and Cnidoscolus 
acontifolius on the radicle length of guinea corn seed. This in vitro cytotoxic result does not, however, agree with previous findings by Erhabor and Idu (2017) on the in vivo acute toxicological effect of the A. barbadensis root extract within the utilized dose range (100 to $400 \mathrm{mg} / \mathrm{kg}$ ).

\section{CONCLUSION}

This study revealed the potential of $A$. barbadensis root extract as a strong scavenger of free radicals with relatively good antimicrobial activities though at moderately high concentrations. Lead and cadmium were not detected in the plant which probably showed lack of contamination of the plant material. It should be noted, however, that the fractions of $\mathrm{AB}$ root were not assessed for antimicrobial, quantitative phytochemical, cytotoxic and genotoxic activities due to insufficient samples. The moderately high nutrient content of the extract may be a possible mechanism for the aphrodisiac property of the plant. The results of the biological activities of $A$. barbadensis root is an indication of its potential use in drug development for managing infectious diseases and other related ailments. Although the results suggest that the extract may be cytotoxic, there is a need to assess the plant in other in vitro and in vivo assays using relevant cell lines, and in long term animal model studies.

List of abbreviations: AB: Aloe barbadensis, DPPH: 1, 1, diphenyl-2picrlhydrazyl, FRAP: ferric reducing power, MIC: minimum inhibitory concentration, MBC: minimum bactericidal concentration.

Conflict of interest: The authors declare that no conflict of interest is in existent.

Acknowledgements: The technical assistance of Prof. D.I. Olorunfemi in the Allium cepa assay is recognized. The management of Pax Herbal Clinic and Research Centre is appreciated for allowing use of their facilities for some of the assays. The authors are also grateful to the University of Pretoria and the University of the Free State for offering Postdoctoral Fellowships to JOE. Prof. Lyndy McGaw is also appreciated for helping to proofread the work.

Funding: This study did not receive any specific fund from any granting agencies in the public, commercial, or not-for-profit sectors. A thesis write-up grants from the University Research and Publication Unit of the University of Benin, Nigeria to JOE is acknowledged.

Ethics approval and consent to participate: The Ethics committee of the Faculty of Life Sciences, University of Benin, Nigeria exempted the study from any formal ethical approval. The need for consent was deemed unnecessary as the semen samples were blindly collected from the stock of the hospitals.

\section{REFERENCES}

ADODO, A. (2012). Nature power: A Christian Approach to Herbal medicine. (3rd ed.). Ewu, Edo State, Nigeria: PAX Herbal Clinic \& Research Laboratories. AHMAD, S., LATIF, A., \& QASMI, I. A. (2003). Aphrodisiac activity of 50\% ethanolic extracts of Myristica fragrans Houtt.(nutmeg) and Syzygium aromaticum (L) Merr. \& Perry.(clove) in male mice: a comparative study. BMC Complement Altern Med., 3(1), 6. https://doi.org/10.1186/1472-6882-3-6 AHMAD, S., LATIF, A., \& QASMI, I. A. (2004). Effect of $50 \%$ ethanolic extract of Syzygium aromaticum (L.) Merr. \& Perry.(clove) on sexual behaviour of normal male rats. BMC Complement Altern Med., 4(1), 17 https://doi.org/10.1186/1472-6882-4-17

AKERELE, O. (1987). The best of both worlds: bringing traditional medicine up to date. Soc Sci Med., 24(2), 177-181. https://doi.org/10.1016/02779536(87)90250-4

AL-FARTOSY, A. J. M, (2011). Antioxidant properties of methanolic extract from Inula graveolens L. Turk J Agric For., 35(6), 591-596. doi:10.3906/tar1010-1268

ANDREWS, J. (2005). BSAC standardized disc susceptibility testing method (version 4). J Antimicrob Chemother., 56(1), 60-76 https://doi.org/10.1093/jac/dki124

ASHAFA, A., GRIERSON, D., \& AFOLAYAN, A. (2008). Antimicrobial activity of extract from Felicia muricata Thunb. J. Biol. Sci, 8(6), 1062-1066 https://doi.org/10.3923/jbs.2008.1062.1066

ASHAFA, A., GRIERSON, D., \& AFOLAYAN, A. (2010). In vitro antioxidant activity of extracts from the leaves of Felicia muricata Thunb. an underutilized medicinal plant in the Eastern Cape Province, South Africa. Afr J Tradit Complement Altern Med, 7(4). https://doi.org/10.4314/ajtcam.v7i4.56695

AYINDE, B., \& AGBAKWURU, U. (2010). Cytotoxic and growth inhibitory effects of the methanol extract Struchium sparganophora Ktze (Asteraceae) leaves. Pharmacogn Mag, 6(24), 293. https://doi.org/10.4103/0973-1296.71795 BARUA, C. C., BORA, M., SAIKIA, B. N., HAZARIKA, M., \& BARUA, I. C. (2015). Quantitative Analysis of Proximate and Mineral Composition of A Few Important Medicinal Plants of North East Region. Int J Appl Biol Pharma Techn. 2015; 6:188-193.

CHE, Q.-M., AKAO, T., HATTORI, M., KOBASHI, K., \& NAMBA, T. (1991) Isolation of a Human Intestinal Bacterium Capable of Transforming Barbaloin to
Aloe-Emodin Anthrone1. Planta Med, 57(01), 15-19. https://doi.org/10.1055/s2006-960007

CHEESBROUGH, M. (2006). District laboratory practice in tropical countries Cambridge university press, United Kingdom.

CHIDAMBARA MURTHY, K. N., SINGH, R. P., \& JAYAPRAKASHA, G. K. (2002). Antioxidant activities of grape (Vitis vinifera) pomace extracts. J Agric Food Chem., 50(21), 5909-5914. https://doi.org/10.1021/jf0257042

DANHOF, I. E. \& MCANALLEY, B. H.. (1983). Stabilized Aloe vera: Effect on Human skin cells. . Drug and Cosmetic Industry, Danhof, I. E. and McAnally, B. H. (1983) Stabilized Aloe vera: Effect on Human skin cells. Drug Cos. Indus. 133:52-106., 52 - 106.

DAVIS, R. H., DONATO, J., HARTMAN, G. M., \& HAAS, R. C. (1994). Antiinflammatory and wound healing activity of a growth substance in Aloe vera. $J$ Am Podiatr Med Assoc., 84(2), 77-81. https://doi.org/10.7547/87507315-84-2-77 EBOJI, O., VENABLES, L., SOWEMIMO, A., SOFIDIYA, M., KOEKEMOER, T., \& VAN DE VENTER, M. (2017). Burkea africana Hook (Caesalpiniaceae) ethanolic extract causes cell cycle arrest at $M$ phase and induces caspase dependent apoptosis. $S$ Afr $J$ Bot, $112, \quad 361$ 367. https://doi.org/10.1016/j.sajb.2017.06.013

EDEOGA HO, G. A. (2000). Nutritional values of some non-conventional leafy vegetable in Nigeria. J Econ Tax Bot., 24, 7-13.

EJIKEME, C. M., EZEONU, C. S., \& EBOATU, A. N. (2014). Determination of physical and phytochemical constituents of some tropical timbers indigenous to Niger Delta area of Nigeria. European Scientific Journal, ESJ, 10(18).

EKHAISE, F., \& RICHARD, F. (2008). Common bacterial isolates associated with the semen of men complaining of infertility in University of Benin Teaching Hospital (UBTH), Benin City, Nigeria. World J Med Sci., 3(1), 28-33.

ELISHA, I. L., DZOYEM, J.-P., BOTHA, F. S., \& ELOFF, J. N. (2015). The efficacy and safety of nine South African medicinal plants in controlling Bacillus anthracis Sterne vaccine strain. BMC Complement Altern Med, 16(1), 5. https://doi.org/10.1186/s12906-015-0980-1

ELOFF, J. N. (1998). A sensitive and quick microplate method to determine the minimal inhibitory concentration of plant extracts for bacteria. Planta Med, 64(08), 711-713. https://doi.org/10.1055/s-2006-957563

EMERUWA, A. (1982). Antibacterial substance from Carica papaya fruit extract. J Nat Prod, 45(2), 123-127. https://doi.org/10.1021/np50020a002

ERHABOR, J. O. (2015). Aphrodisiac potential and biosafety evaluations of the ethanolic extract of Aloe barbadensis Mill. Root. (Ph.D), University of Benin, Benin City, Nigeria.

ERHABOR, J., IDU, M., \& UDO, F. (2013). Ethnomedicinal survey of medicinal plants used in the treatment of male infertilty among the IFA Nkari People of Ini Local Government area of Akwa Ibom State, Nigeria. Res. J. Recent Sci., ISSN, 2277, 2502.

ERHABOR, J., OSHOMOH, E., TIMOTHY, O., OSAZUWA, E., \& IDU, M. (2013). Antimicrobial activity of the methanol and aqueous leaf extracts of Emilia coccinea (Sims) G. Don. Niger. J. Biotechnol., 25, 37-45

ERHABOR, J. O., \& IDU, M. (2017). Aphrodisiac potentials of the ethanol extract of Aloe barbadensis Mill. root in male Wistar rats. BMC Complement Altern Med, 17(1), 360. https://doi.org/10.1186/s12906-017-1866-1 FAJANA, A. (2013). cytotoxic and growth inhibitory effects of the methanol extract of Tridax procumbens linn (Asteraceae). J Pharmacogn Phytochem., 2(1). FALODUN, A., \& IRABOR, E. E. (2008). Phytochemical, proximate, antioxidant and free radical scavenging evaluations of Calliandria surinamensis. Acta Poloniae Pharma Drug Res, 65, 571-575.

FALODUN A, U. A., ODIM EE, OGUAZU E. . (2011). Phytochemical and antioxidant properties of Pericarp of Garcinia kola extract. Bayero J Pure Appl Sci., 4(1), 105-109. https://doi.org/10.4314/bajopas.v4i1.23

GAUTHAMAN, K., ADAIKAN, P., \& PRASAD, R. (2002). Aphrodisiac properties of Tribulus Terrestris extract (Protodioscin) in normal and castrated rats. Life Sci, 71(12), 1385-1396. https://doi.org/10.1016/s0024-3205(02)01858 1

GODWIN, A., \& PRABHU, H. R. (2006). Lipid peroxidation of fish oils. Indian J Clin Biochem, 21(1), 202-204. https://doi.org/10.1007/bf02913098

GRANT, W. F. (1994). The present status of higher plant bioassays for the detection of environmental mutagens. Mut Res, 310(2), 175 185. https://doi.org/10.1016/0027-5107(94)90112-0

HARBORNE, J., GREENHAM, J., \& WILLIAMS, C. (1973). Phytochemical analysis. Chapman and Hall company Ltd, London, 1, 5-6.

HORWITZ, W., \& LATIMER, G. (2000). Official Methods of Analysis of AOAC International, Gaithersburg MA, USA. Association of Official Analytical chemist.

HOUR S.S, A. E., CARTE RD. . ( 1980). Concentration of water melon juice. Journal of Food Science, 45, 718-719.

IBADIN, O., \& IBEH, I. (2008). Bacteriospermia and sperm quality in infertile male patient at University of Benin Teaching Hospital, Benin City, Nigeria. Mala J Microbiol, 4(2), 65-67. https://doi.org/10.21161/mjm.12108

IDU, M., ASOWATA, I. AND ERHABOR, J.O. . (2011). Preliminary antimicrobial and Phytochemical study of the aqueous, ethanol, methanol and chloroform extracts of the leaves of Napoleona imperialis P. Beauv (Lecythidiaceae). Journal of Plant Development Science, 3, 225 - 231. 
IDU, M., ERHABOR, J. O., \& OVUAKPORIE-UVO, O. (2014) Ethnomedicinal plants used by the Idoma people-Benue State, Nigeria. American Journal of Ethnomedicine, 1(1).

IKPEFAN, E. O., AYINDE, B., \& GITA, T. (2013). In vitro comparative cytotoxic and growth inhibitory effects of the methanol extracts of the leaf, stem and root barks of Cnidoscolus acontifolius (Mill.) Johnst (Euphorbiaceae). International Journal of Bioassays, 2(2), 445-449.

IWU, M. M. (2014). Handbook of African Medicinal Plants: CRC press.

JOSEPH, B., \& RAJ, S. J. (2010). Pharmacognostic and phytochemical properties of Aloe vera linn an overview. International journal of pharmaceutical sciences review and research, 4(2), 106-110.

KIBAR, B., \& KIBAR, H. (2017). Determination of the nutritional and seed properties of some wild edible plants consumed as vegetable in the Middle Black Sea Region of Turkey. S Afr J Bot., 108, 117125. https://doi.org/10.1016/j.sajb.2016.10.011

KIBAR, B., \& TEMEL, S. (2016). Evaluation of mineral composition of some wild edible plants growing in the eastern Anatolia region grasslands of Turkey and consumed as vegetable. J. Food Process Pres. 40(1), 56-66.

KOMOLAFE, O.I, AWONIYI, A.O. (2013). The prevalence of microbia isolates associated with infertility in men attending clinic in OAUTHC, Ile - Ife. International Journal of Microbiology Research and Reviews 1(5), 88-91.

KUMAR, R., SIVAKUMAR, T., SUNDERAM, R., GUPTA, M., MAZUMDAR,

U., GOMATHI, P., . . . MURUGESH, K. (2005). Antioxidant and antimicrobial activities of Bauhinia racemosa L. stem bark. Braz J Med Biol Res, 38(7), 10151024. https://doi.org/10.1590/s0100-879x2005000700004

LEONG, L., \& SHUI, G. (2002). An investigation of antioxidant capacity of fruits in Singapore markets. Food Chem, 76(1), 69-75.

LIN, J. Y. \&. TANG., C. Y. (2007). Determination of total phenolic and flavonoid contents in selected fruits and vegetables, as well as their stimulatory effects in mouse splenocyte proliferation. Food Chemistry, 101, 140 - 147 https://doi.org/10.1016/j.foodchem.2006.01.014

LOMBARDO, F., SANSONE, A., ROMANELLI, F., PAOLI, D., GANDINI, L., \& LENZI, A. (2011). The role of antioxidant therapy in the treatment of male infertility: an overview. Asian J Androl., 13(5), 690 https://doi.org/10.1038/aja.2010.183

MAENTHAISONG, R., CHAIYAKUNAPRUK, N., NIRUNTRAPORN, S., \& KONGKAEW, C. (2007). The efficacy of aloe vera used for burn wound healing: a systematic review. Burns, 33(6), 713-718. https://doi.org/10.1016/j.burns.2006.10.384

MOMOH, A. R. M., IDONIJE, O. B., OKOGBO, F., OKHIAI, O., OKOLO, P. O., TURAY, A. A., \& MOMOH, A. A. (2011). A monomicrobial infection of Staphylococcus aureus associated with Erectile Dysfunction-A CASE REPORT. MONGALO, N., MCGAW, L., FINNIE, J., \& VAN STADEN, J. (2017). Pharmacological properties of extracts from six South African medicinal plants used to treat sexually transmitted infections (STIs) and related infections. S Afr Bot., 112, 290-295. https://doi.org/10.1016/j.sajb.2017.05.031

MOTLHATLEGO, K., NJOYA, E. M., ABDALLA, M., ELOFF, J., \& MCGAW, L. (2018). The potential use of leaf extracts of two Newtonia (Fabaceae) species to treat diarrhoea. $S$ Afr $J$ Bot., 116, 25-33. https://doi.org/10.1016/j.sajb.2018.02.395

MUANYA, C., \& ODUKOYA, O. (2008). Lipid peroxidation as index of activity in aphrodisiac herbs. Plant Sci, 3(1), 92-98. https://doi.org/10.3923/jps.2008.92.98

NA, B. (1991). Calcium Homeostasis. In Textbook of Endocrine physiology (2nd edition ed., pp. 276-308). Dallas: Griffin and Ojeda.

OBADONI, B., \& OCHUKO, P. (2002). Phytochemical studies and comparative efficacy of the crude extracts of some haemostatic plants in Edo and Delta States of Nigeria. Global J Pure Appl Sci., 8(2), 203-208. https://doi.org/10.4314/gjpas.v8i2.16033

OBICI, S., OTOBONE, F. J., DA SILVA SELA, V. R., ISHIDA, K., DA SILVA, J. C., NAKAMURA, C. V., CORTEZ, D.A.G. \& AUDI, E. A. (2008). Preliminary toxicity study of dichloromethane extract of Kielmeyera coriacea stems in mice and rats. $J$ Ethnopharmacol., 115(1), 131-139. https://doi.org/10.1016/j.jep.2007.09.013

ODESANMI, O. S., OJOKUKU, S. A., APENA, A., BIKOMO, O. E., \& LAWAL, R. A. (2012). Nutritional prospect of an aphrodisiac Microdermis

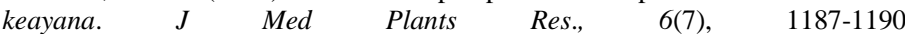
https://doi.org/10.5897/jmpr11.919

OHKAWA, H., OHISHI, N., \& YAGI, K. (1979). Assay for lipid peroxides in animal tissues by thiobarbituric acid reaction. Anal Biochem., 95(2), 351358. https://doi.org/10.1016/0003-2697(79)90738-3

OKIGBO, R., \& AJALIE, A. (2005). Inhibition of some human pathogens with tropical plant extracts-Chromolaena odorata and Citrus aurantifolia, and some antibiotics. International Journal of Molecular Medicine and Advance Sciences, 1(1), 34-40.

OKIGBO, R., EME, U., \& OGBOGU, S. (2008). Biodiversity and conservation of medicinal and aromatic plants in Africa. Biotechnol. Mol. Biol. Rev, 3(6), 127 134.

OKOLIE, N., ISRAEL, E., \& FALODUN, A. (2011). In-vitro evaluation of antioxidant potential of Rauwolfia vomitoria root extract and its inhibitory effect on lipid peroxidation as indication of aphrodisiac properties. Pharm Chem J., 45(8), 476-480. https://doi.org/10.1007/s11094-011-0660-5

OKONOFUA, F. E., AKO-NAI, K., \& DIGHITOGHI, M. (1995). Lower genital tract infections in infertile Nigerian women compared with controls. Sex Transm Infect., 71(3), 163-168. https://doi.org/10.1136/sti.71.3.163

OLORUNFEMI, D., OGIESERI, U., \& AKINBORO, A. (2011). Genotoxicity screening of industrial effluents using onion bulbs (Allium cepa L.). J Appl Sci Environ Manage, 15(1). https://doi.org/10.4314/jasem.v15i1.65700

OLORUNFEMI, D. I., LELEKUMO, E., AND UBAH, M. (2014). Toxicity assessment of Bioremediated contaminated domestic water sources in NigerDelta by a phytogentoxicity test. . Nigerian Journal of Life Sciences, 4 (2), 140 -150 .

OLOWOKUDEJO, J., KADIRI, A., \& TRAVIH, V. (2008). An ethnobotanical survey of herbal markets and medicinal plants in Lagos State of Nigeria. Ethnobotanical leaflets, 2008(1), 116.

OTANG, W. M., GRIERSON, D. S., \& NDIP, R. N. (2012). Phytochemical studies and antioxidant activity of two South African medicinal plants traditionally used for the management of opportunistic fungal infections in HIV/AIDS patients. BMC Complement Altern Med., $12(1), \quad 43$ https://doi.org/10.1186/1472-6882-12-43

OYEWOPO, A., OREMOSU, A., AKANG, E., NORONHA, C., \& OKANLAWON, A. (2011). Effects of Aloe Vera (Aloe barbadensis) aqueous leaf extract on testicular weight, sperm count and motility of adult male SpragueDawley rats. Journal of American Science, 7(4), 31-34.

PRASAD, P. S. H., \& RAMAKRISHNAN, N. (2012). In vitro lipid peroxidation assay of Rumex vesicarius L. Int J Pharm Pharm Sci, 4(Suppl 1), S368-S370.

RAGHUVEER, C., CHAWALA, V. K., SONI, N. D., JAYANT, K., AND, \&

VYAS, R. K. (2010). Oxidative stress and rile of antioxidants in male infertility. Pakistan Journal of Physiology, 6(2), 54-59.

RANK, J., \& NIELSEN, M. (1994). Evaluation of the Allium anaphase-telophase test in relation to genotoxicity screening of industrial wastewater. Mut Res, 312(1), 17-24. https://doi.org/10.1016/0165-1161(94)90004-3

ROBBERS, J. E., \& TYLER, V. E. (1999). Tyler's herbs of choice. The therapeutic use of phytomedicinals: Haworth Press Inc.

ROBERT, K., GRANNER, D. K., \& MAYES, P. A. M. (2003). Harper's Illustrated Biochemistry

ROSS, I. (1999). Medicinal plants of the world, Part 1: Chemical constituents, Traditional and Modern medicinal uses. New Jersery: Humana Press Inc, 119125

SAHU, P. K., GIRI, D. D., SINGH, R., PANDEY, P., GUPTA, S. SHRIVASTAVA, A. K., . . PANDEY, K. D. (2013). Therapeutic and medicinal uses of Aloe vera: a review. Pharmacology \& Pharmacy, 4(08), 599.

SHAMIM, S., AHMED, S. W., \& AZHAR, I. (2004). Antifungal activity of Allium, Aloe, and Solanum species. Pharm Biol., 42(7), 491-498. https://doi.org/10.3109/13880200490891845

SHARMA, R., \& LALL, N. (2014). Antibacterial, antioxidant activities and cytotoxicity of plants against Propionibacterium acnes. South African Journal of Science, 110(11-12), 01-08.

SMAKA-KINCL, V., STEGNAR, P., LOVKA, M., \& TOMAN, M. J. (1996). The evaluation of waste, surface and ground water quality using the Allium test procedure. Mut Res, 368(3-4), 171-179. https://doi.org/10.1016/s01651218(96)90059-2

SMITH, H., EDUFUNKE, I., \& ADEYEMI, R. (2000). Toxicity test of water homogenate of Cissus populnea stem in mice and its effects on weights of some organs, serum gonadotropins, lipids and uric acid in male albino rats. Nig $Q J$ Hosp Med., 10(3), 224-227. https://doi.org/10.4314/nqjhm.v10i3.12475

SODIPO OA, A. M., KOLAWOLE, FB, ODUTUGA AA. . (1991). Saponin is the active antifungal principle in Garcinia kola Heckle seed. . Bioscience Research Communication, 3, 171.

SOFOWORA, A. (1993). Medicinal Plants and Traditional Medicine in Africa. Ibadan, Nigeria: Spectrum Books Limited.

SOGBAIKE, D., OGUNDAINI, A., \& ADESANYA, S. (2002). The effects of some synthesised stilbene analogues on Artemia salina naupalii and germination of Sorghum bicolor seeds. Niger J Nat Prod Med, 6(1), 1925. https://doi.org/10.4314/ninpm.v6i1.11686

STEPHEN, J. (1980). Adriamycin induced genetic toxicity as demonstrated by the Allium test. Cytologia, 45(4), 769-777.

SUDHA, G., PRIYA, M. S., SHREE, R. I., \& VADIVUKKARASI, S. (2011). In vitro free radical scavenging activity of raw pepino fruit (Solanum muricatumaiton). Int J Curr Pharm Res, 3(2), 137-140.

SUMALATHA, K., KUMAR, S., \& LAKSHMI, S. M. (2010). Review on natural aphrodisiac potentials to treat sexual dysfunction. Int $J$ Pharm Ther, 1 , $10-18$

TANAKA, M., MISAWA, E., ITO, Y., HABARA, N., NOMAGUCHI, K., YAMADA, M., . . . INAGAKI, M. (2006). Identification of five phytosterols from Aloe vera gel as anti-diabetic compounds. Biol Pharm Bull, 29(7), 14181422. https://doi.org/10.1248/bpb.29.1418

TIMOTHY, O., IDU, M., OLORUNFEMI, D., \& OVUAKPORIE-UVO, O (2014). Cytotoxic and genotoxic properties of leaf extract of Icacina trichantha Oliv. S Afr J Bot., 91, 71-74. https://doi.org/10.1016/j.sajb.2013.11.008 
Trease, G. (1996). Trease and Evans pharmacognosy 14th edition wb Ssuvnder company limited. London Pp191-293.

URAKU A.J., O. A., OGBANSHI ME, ONUOHA SC. . (2016). Nutritive and anti - nutritive potentials of Cymbopopgon citratus leaves. American Journal of Food and Nutrition, 20166(1), $14-22$.

USMAN, H., HARUNA, A., AKPULU, I., ILYAS, M., AHMADU, A., \& MUSA, Y. (2005). Phytochemical and antimicrobial screenings of the leaf extracts of Celtis integrifolia Lam. J. Trop. Biosci, 5(2), 72-76.

VENABLES, L., KOEKEMOER, T., VAN DE VENTER, M., \& GOOSEN, E. (2016). Isoalantolactone, a sesquiterpene lactone from Artemisia afra Jacq. ex Willd and its in vitro mechanism of induced cell death in HeLa cells, S Afr J Bot., 103, 216-221. https://doi.org/10.1016/j.sajb.2015.08.016

WEST, D. P., \& ZHU, Y. F. (2003). Evaluation of Aloe vera gel gloves in the treatment of dry skin associated with occupational exposure. Am J Infect Control., 31(1), 40-42. https://doi.org/10.1067/mic.2003.12

YAGI, A., SATO, Y., MIWA, Y., KABBASH, A., MOUSTAFA, S., SHIMOMURA, K., \& EL-BASSUONY, A. (2006). Ribosomal DNA sequence analysis of different geographically distributed Aloe vera plants: Comparison with clonally regenerated plants. Saudi Pharmaceutical Journal, 14(3/4), 208.

YAKUBU, M., AKANJI, M., \& OLADIJI, A. (2005). Aphrodisiac potentials of the aqueous extract of Fadogia agrestis (Schweinf. Ex Hiern) stem in male albino rats. Asian $J$ Androl., 7(4), 399-404. https://doi.org/10.1111/j.17457262.2005.00052.X

YAKUBU, M., AKANJI, M., \& OLADIJI, A. (2007). Male sexual dysfunction and methods used in assessing medicinal plants with aphrodisiac potentials. Pharmacognosy Reviews, 1(1), 49.

YEBPELLA, G., MM, A. H., HAMMUEL, C., MAGOMYA, A., AGBAJI, A. \& OKONKWO, E. (2011). Phtyochemical screening and comparative study of antimicrobial activity of Aloe vera various extracts. Afr J Microbiol Res., 5(10), 1182-1187. https://doi.org/10.5897/ajmr10.818

YEN, G. C., DUH, P. D., \& TSAI, C. L. (1993). Relationship between antioxidant activity and maturity of peanut hulls. J Agric Food Chem., 41(1), 6770. https://doi.org/10.1021/jf00025a015

ZAMBLÉ, A., SAHPAZ, S., BRUNET, C., \& BAILLEUL, F. (2008). Effects of Microdesmis keayana roots on sexual behavior of male rats. Phytomedicine 15(8), 625- 629. https://doi.org/10.1016/j.phymed.2007.10.002 